Japan. J. Med. Sci. Biol., 41, 31-36, 1988.

Short Communication

\title{
LABORATORY AND FIELD ASSESSMENT OF MOLLUSCICIDAL ACTIVITY OF B-2 AGAINST ONCOMELANIA HUPENSIS, THE VECTOR SNAIL OF SCHISTOSOMIASIS IN CHINA
}

Mankwong WONG, Chuanbin XIA, Meili CHEN, Chuxiang ZHANG, Peishan MAO, Guoqiang NEI and Yukio HOSAKA1

Provincial Research Institute of Parasitic Diseases, Yueyang City, Hunan, China, and 1Department of Parasitology, National Institute of Health, Kamiosaki, Shinagawa-ku, Tokyo 141

(Received April 15, 1988. Accepted June 8, 1988)

SUMMARY: Molluscicidal activity of B-2 (sodium 2,5-dichloro-4-bromophenol; called as Phebrol and registered in WHO as OMS 3012) was evaluated in a laboratory and the field trials were performed in two different localities in Yueyang city, China, for control of Oncomelania hupensis. B-2 was effective against $O$. hupensis both in the laboratory and in the field. A dosage of $50 \mathrm{~g} / \mathrm{m}^{2}$ in $10 \%$ granular form or $20 \mathrm{ml} / \mathrm{m}^{2}$ in $25 \%$ liquid form of B-2 would be recommendable as a standard mollusciciding dose for control of $O$. hupensis.

Laboratory and field assessment of B-2 (sodium 2,5-dichloro-4-bromophenol) against Oncomelania nosophora, the intermediate host of Schistosoma japonicum in Japan, was made by Kajihara et al $(1,2)$. The results indicated its promising molluscicidal activity against the target snail and its toxicity to non-target animals seemed to be rather low. Further laboratory and field studies with this chemical revealed the molluscicidal effect on Oncomelania quadrasi, the vector snail of schistosomiasis in the Philippines (3). For aquatic snails, Taira et al. (4)

保阪幸男(国立予防衛生研究所寄生虫部) 
reported that B-2 showed a molluscicidal activity against eggs, juveniles and adults of Lymnaea ollula, the intermediate host of Fasciola sp. in Japan. Thus B-2 seemed to be a very effective molluscicide against oncomelaneid snails as well as $L$. ollula and is now used as a practical molluscicide for control of $O$. nosophora in Japan. This chemical is also called Phebrol and registered in WHO (OMS 3012) as a recommendable molluscicide.

The present paper deals with laboratory and preliminary field trials with B-2 as a potential molluscicide against Oncomelania hupensis, the intermediate host of S. japonicum in China.

In the laboratory trial, Komiya's technique (5) was adopted to bring the snails in contact with the chemical. Thirty snails were exposed to each of several consecutive twofold dilutions of the $25 \%$ liquid form at $27 \mathrm{C}$ for $48 \mathrm{hr}$. Triplicate tests with the serial dilution of the chemical were carried out and $\mathrm{LC}_{50}$ and $\mathrm{LC}_{90}$ were calculated by the method of Litchfield and Wilcoxon (6). Figure 1 shows the result of laboratory trials. $\mathrm{LC}_{50}$ and $\mathrm{LC}_{90}$ in concentration of the active ingredient of the chemical were $0.378 \mathrm{ppm}$ and $0.809 \mathrm{ppm}$, respectively. The $\mathrm{LC}_{50}$ values of $\mathrm{B}$ 2 against $O$. hupensis, $O$. nosophora (1) and $O$. quadrasi (3) are shown in Table I.

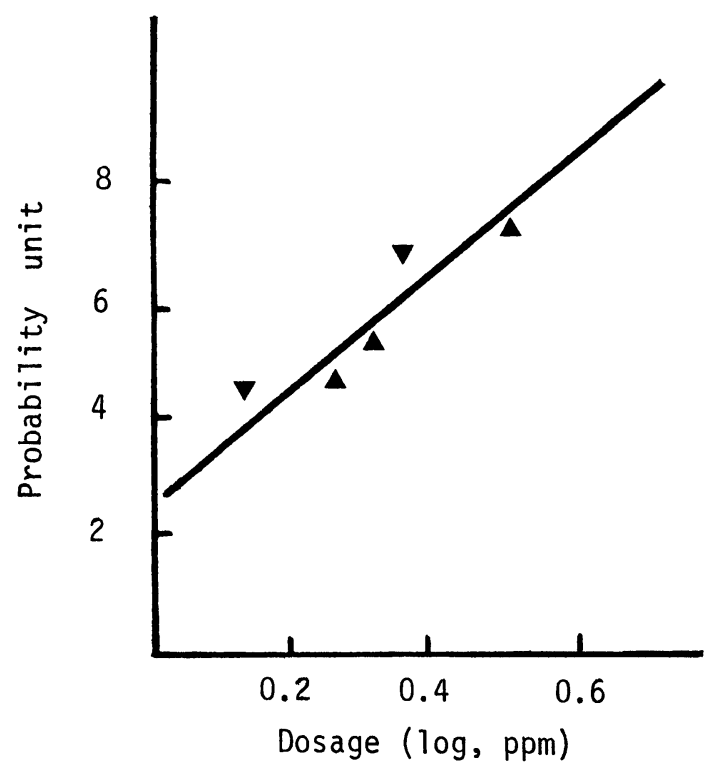

Fig. 1. Dosage-effect curve of B-2 on Oncomelania hupensis in the laboratory. 
Table I. $\mathrm{LC}_{50}$ of $\mathrm{B}-2^{*}$ against Oncomelania snails determined in the laboratory

\begin{tabular}{ccl}
\hline Snail & $\mathrm{LC}_{50}(\mathrm{ppm})$ & \multicolumn{1}{c}{ Reference } \\
\hline Oncomelania hupensis & 0.38 & \\
Oncomelania nosophora & $0.38-0.54$ & Kajihara et al. (1979a) \\
Oncomelania quadrasi & $0.47-0.55$ & Hosaka et al. (1984) \\
\hline
\end{tabular}

$* 25 \%$ liquid form of B-2 was used.

Field trials were performed in two different localities, Junshan and Louxiwan in Yueyang city, Hunan Province, an endemic area of schistosomiasis in China. B-2 in either $25 \%$ liquid form or $10 \%$ granular form was applied in each of 4 $\mathrm{m}^{2}$ quadrates which were set in the snail habitat and were surrounded with a manmade canal of about $30 \mathrm{~cm}$ in depth. Sixteen quadrates were made in Junshan field. The grass of eight quadrates was mowed to about $10 \mathrm{~cm}$ before chemical application. In other eight quadrates, grass of about $30 \mathrm{~cm}$ in height was not mowed. In the second trial in Louxiwan, the grass of all quadrates was mowed as in the eight quadrates in Junshan. The chemical in liquid form was sprayed with handy sprayers in each quadrate at a dosage of $0 \mathrm{ml}, 5 \mathrm{ml}, 10 \mathrm{ml}$ or $20 \mathrm{ml} / \mathrm{m}^{2}$. The chemical in granular form at a dosage of $0 \mathrm{~g}, 12.5 \mathrm{~g}, 25 \mathrm{~g}$ or $50 \mathrm{~g} / \mathrm{m}^{2}$ was spread by hand as evenly as possible. Before and after treatment, snalis were sampled on day 0 and/or 3, 7 and 14. Snails from five points in each quadrate were collected and observed for their fate. The results are shown in Table II. The treatment with doses of $10 \mathrm{ml}$ and $20 \mathrm{ml} / \mathrm{m}^{2}$ of $25 \%$ liquid form gave snail mortality rates higher than $80 \%$ after 14 days of chemical application. Mortalities of snails treated with $50 \mathrm{~g} / \mathrm{m}^{2}$ of granular form of B-2 were higher than $85 \% 7$ days and 14 days after treatment with the chemical. Although a dose of $25 \mathrm{~g} / \mathrm{m}^{2}$ of granular form gave snail mortalities of $81 \%$ or lower than $75 \% 7$ and 14 days after treatment, the mortality of snails from the fields in which grass was mowed was rather high. During the second trial in Louxiwan field, post-treatment snail sampling was continued for 7 days after application of the chemical but not after because of a flood of the experimental field. The result of this trial seems to be similar to that of the first trial in Junshan as shown in Table III. 


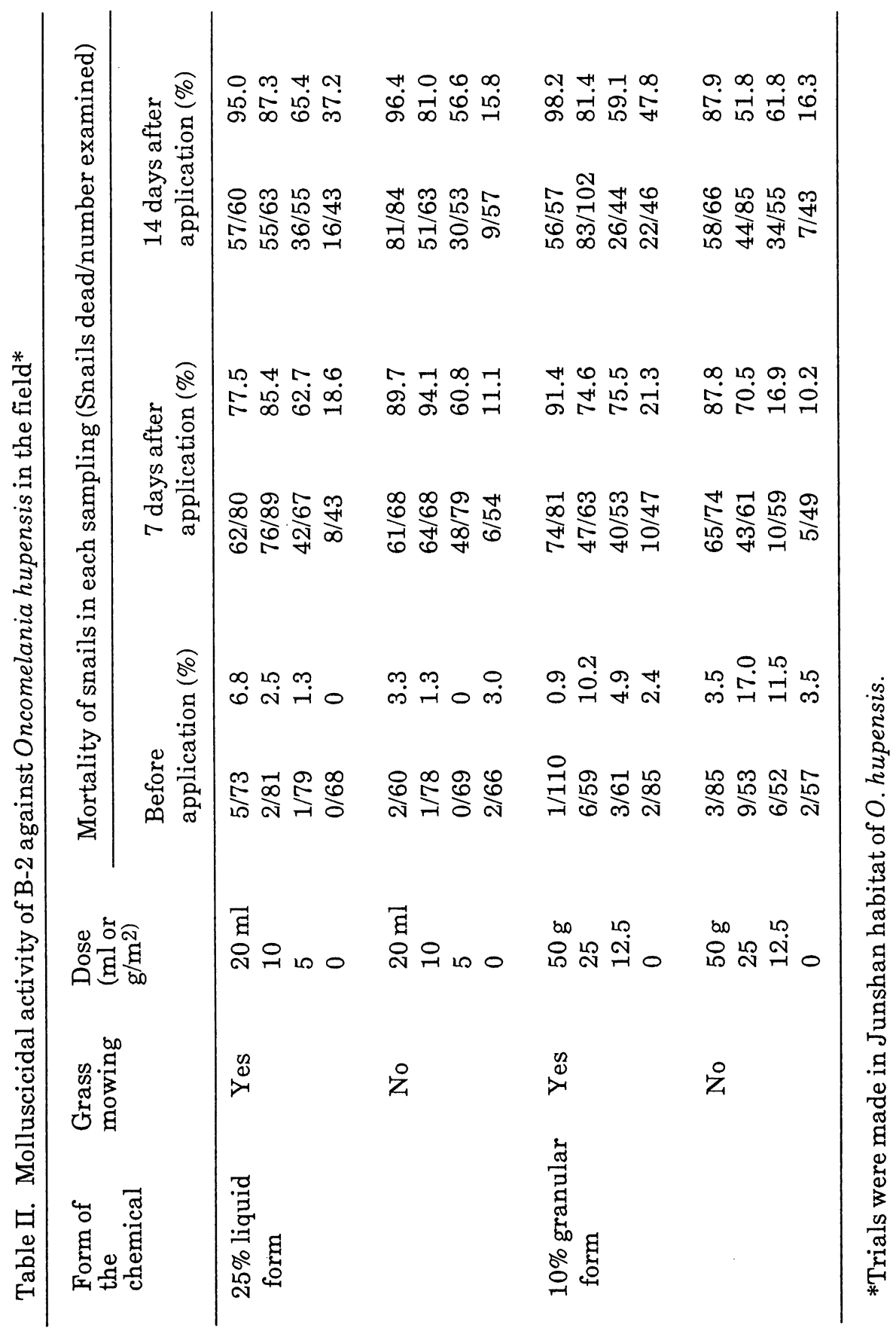




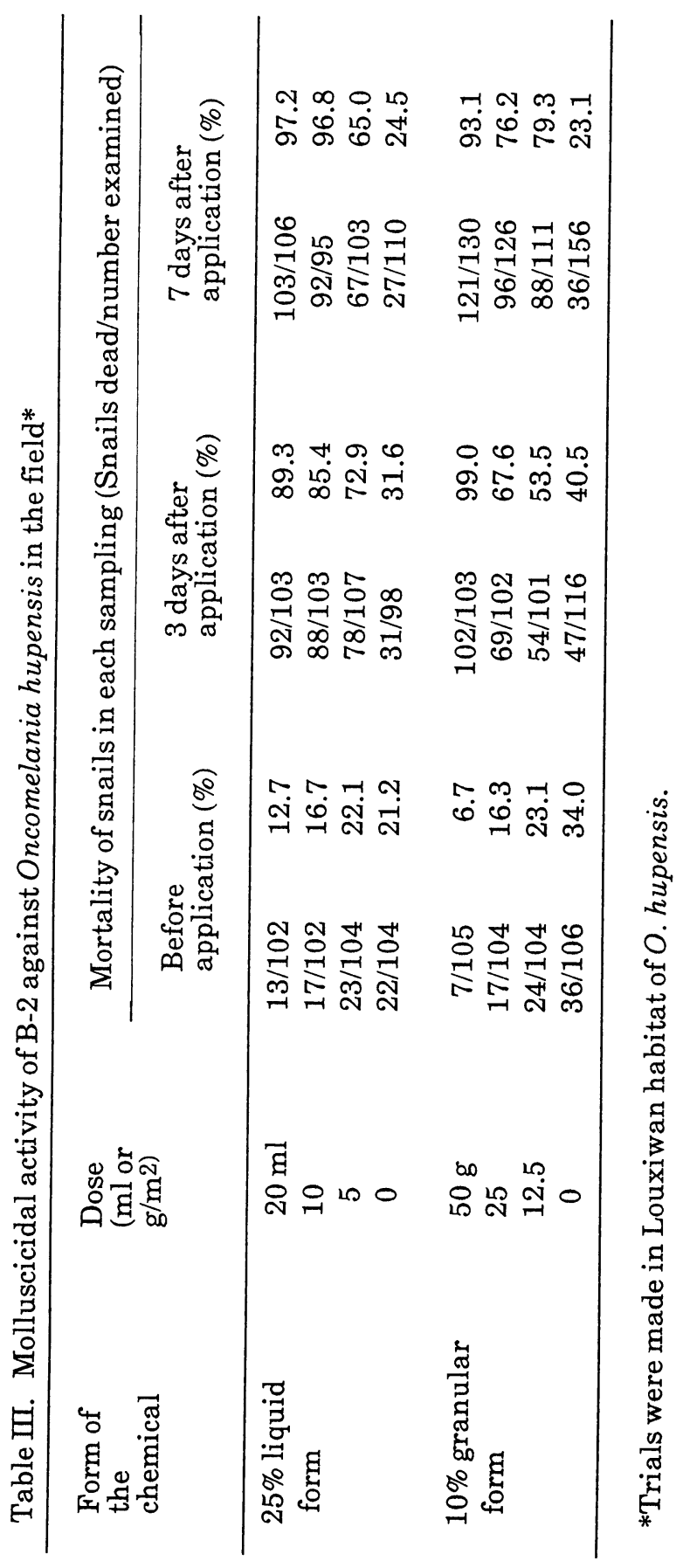


For the practical use of B-2 in control of $O$. nosophora in Japan, the dosage of $25 \mathrm{~g} / \mathrm{m}^{2}$ in $10 \%$ granular form or $10 \mathrm{ml} / \mathrm{m}^{2}$ in $25 \%$ liquid form has been adopted as a standard mollusciciding dose (2). To obtain the same level of molluscicidal activity of the compound for control of $O$. hupensis in China, a higher dose of the chemical than that for $O$. nosophora in Japan would be needed. From the result of this field trial, the dosage of $50 \mathrm{~g} / \mathrm{m}^{2}$ in $10 \%$ granular form or $20 \mathrm{ml} / \mathrm{m}^{2}$ in $25 \%$ liquid form of B-2 would be required for control of $O$. hupensis in China.

\section{ACKNOWLEDGEMENT}

The authors are indebted to Nippon Chemical Industry Ltd., for supplying B-2.

\section{REFERENCES}

1. Kajihara, N., Horimi, T., Minai, M. and Hosaka, Y. (1979a): Japan. J. Med. Sci. Biol., 32, 185-188.

2. Kajihara, N., Horimi, T., Minai, M. and Hosaka, Y. (1979b): Japan. J. Med. Sci. Biol., 32, 225-228.

3. Hosaka, Y., Hashiguchi, J., Sakata, Y., Banez, E. A. and Blas, B. L. (1984): Japan. J. Parasitol., 33, 55-58.

4. Taira, N., Yoshihara, S., Ikeda, I. and Ueno, H. (1977): Bull. Nat. Inst. Anim. Hlth., 75, 16-22 (text in Japanese).

5. Komiya, Y., Hosaka, Y. and Yasuraoka, K. (1962): Japan. J. Med. Sci. Biol., 15, 41-51.

6. Litchfield, J. Y., Jr. and Wilcoxon, F. (1949): J. Pharmacol. Exptl. Therap., 96, 99-113. 